\title{
Physico-chemical and Bacteriological Water Quality Evaluation of the Four Tributaries in Mt. Matutum Protected Landscape (MMPL), South Cotabato, Philippines
}

\author{
Tres Tinna B. Martin ${ }^{1}$, Gerald G. Lobredo ${ }^{2}$, Emmanuel P. Leaño ${ }^{3}$, Maximo C. Aljibe ${ }^{4}$ \\ and Edna P. Oconer ${ }^{12}$
}
${ }^{1}$ Science Department, College of Natural Science and Mathematics, Mindanao State University-General San- tos City (Corresponding author: tres1203@yahoo.com)
${ }^{2}$ Research and Development Center, Mindanao State University-General Santos City
${ }^{3}$ Department of Biology, Central Mindanao University
${ }^{4}$ Sultan Kudarat State University

Received: July 31, 2017; Accepted: December 12, 2017

\begin{abstract}
Healthy riverine systems provide ecological services that can be translated into human use and consumption. However, human activities cause environmental degradation limiting available pristine water supply and raising public health concerns. In the present study, four tributaries surrounding Mt. Matutum Protected Landscape (MMPL) were selected (Glandang, Linan, Kawit, and Amlok) for evaluation of their physicochemical and microbial characteristics between wet and dry season. The $\mathrm{pH}$ and total dissolved solids (TDS) of the river waters ranged from 6.75-8.68 and 55.96-221.89 ppm, respectively, with a pronounced $\mathrm{pH}$ fluctuation and TDS increase in Glandang and Linan tributaries from upstream to downstream stations. All tributaries showed varying dissolved oxygen (DO) levels upstream but become relatively stable downstream. All DO values, however, are below the standard limit set for freshwater quality. In terms of microbial load, total coliform ranged from $51-275 \mathrm{cfu} / \mathrm{ml}$ while $E$. coli showed absence $(0 \mathrm{cfu} / \mathrm{ml})$ to as high as $77 \mathrm{cfu} / \mathrm{ml}$. Higher total coliform counts were observed on Kawit and Amlok tributaries which are situated in areas that are relatively more forested than the other two rivers. Presence of E. coli was also detected in the water samples from all tributaries. Temporal variation is significant indicating increased $\mathrm{pH}$, TDS and microbial load during the wet season and DO during the dry season. The present microbial load of the four tributaries would restrict the utilization of water resource and necessitate proper treatments prior to domestic use.
\end{abstract}

Keywords: coliform, dissolved oxygen (DO), Escherichia coli, total dissolved solids (TDS), Mt. Matutum Protected Landscape

Access to clean water is a basic human right. Water supply can be obtained from various sources: surface waters, rainfall and groundwaters. However, as more and more forest lands become degraded over time, these water resources tend to decline and water quality becomes compromised. Thus, water supply becomes limited for human use (Rout and Sharma, 2011).

In South Cotabato, Region XII, Mt. Matutum is a protected landscape known to contain watersheds that support the water requirements of the surrounding communities. It supplies $25 \%$ of the water requirement of South Cotabato, Sarangani Province and General Santos City for domestic use, agriculture, industry and commercial activities. However, because of human encroachment, the quality of water supply becomes degraded. Overgrazing and deforestation cause siltation and shrinkage of stream flows (Joshi et al., 2009). Poor water management, inadequate waste disposal practices and other domestic activities (Calin and Rosu, 2011) all contribute to the pollution of surface waters. This pressing concern warrants water quality assessment and monitoring activities, yet no such assessment has been done for the low-order streams and creeks in Mt. Matutum.

In MMPL, the DENR conducted a water quality monitoring with researchers from various universities. The monitoring included evaluation of parameters like $\mathrm{pH}$, dissolved oxygen (DO), nitrates, phosphates and chlorides for two periods. However, of the many parameters to be evaluated 
for water quality, four have been considered to constitute the minimum criteria for classification, namely: $\mathrm{DO}, \mathrm{pH}$, biological oxygen demand (BOD) and total coliform organisms (DENR, 1990).

Dissolved oxygen (DO) refers to the amount of gaseous oxygen dissolved in water through diffusion from the surrounding air, by aeration and via photosynthesis (Nduka et al., 2008). DO in surface water is used by all forms of aquatic life. This parameter is measured and monitored to assess the ecological health status of lakes and streams (Perlman, 2014). BOD gives the amount of oxygen required by aerobic aquatic organisms for metabolizing available organic matter in water. This parameter reflects the amount of biologically available organic matter in water. It is used to measure the strength of wastes present in water and to identify the appropriate method for the wastewater treatment (Ajayi et al, 2016). For water quality assessment, DENR AO 2016-08 set the DO standard value at $5 \mathrm{mg} / \mathrm{L}$ for freshwater bodies classified for drinking, bathing and other direct contact activities.

The $\mathrm{pH}$ determines the suitability of water for various uses. The World Health Organization (WHO) in 2004 set the standard $\mathrm{pH}$ range at 6.58.5. This standard is also adopted in the DENR Administrative Order 34 in 1990 as water quality guidelines in the Philippines. Generally, $\mathrm{pH}$ controls the chemical state of many nutrients including DO, phosphates and nitrates (Kushwa et al., 2011).

Aside from physicochemical factors, the water quality also depends on its microbiological conditions (Amanaditou et al., 2003). Microbiological analyses are indispensable in water quality studies especially considering its implication on public health (Yogendra and Puttaiah, 2008, Amanaditou et al., 2003, Malini et al., 2003, Venkateswarlu, 1993). This usually includes bacteriological tests on total plate count, total coliforms, fecal coliforms, Escherichia coli, and enterococci (DOW, 2005). Total coliform count does not necessarily indicate water contamination by fecal material (NHRMC, 2003). Their presence in water stream however possibly detects the existence of diseasecausing organisms such as fecal coliforms, E. coli and other parasites (Ahnwange et al., 2012). A trend of increasing fecal coliform count in rivers and streams depicts intrusion of people and human activities, accumulating organic and inorganic pollutants thus, endangering clean water sources from coliform bacteria (Ngidlo, 2013, Tripathi and Sharma 2011, Line, 2003).
Assessing water quality is more insightful using physicochemical parameters to lay down the actual conditions of the water. These parameters are often used to evaluate whether or not the water resources could be suitable for drinking, bathing, recreation, agricultural use and other industrial activities (DENR, 2014, Tampus et al., 2012). Parameters not meeting the set standards may indicate presence of natural or anthropogenic disturbances affecting the water quality of the river and other aquatic systems. This study aimed therefore to assess the physicochemical characteristics and microbial load of the four selected tributaries around MMPL by comparing these properties with the set standard values and by determining temporal variation in the water quality parameters between different sampling periods.

\section{Materials and Methods}

\section{Study Area}

Mt. Matutum is an ecological landscape identified as a key biodiversity area in the Philippines located at $6^{\circ} 22.00^{\prime} \mathrm{N}$ and $125^{\circ} 5.00^{\prime} \mathrm{E}$ (Figure 1). It forms the headwaters and catchment area for several drainages emptying into Sarangani Bay and provides $25 \%$ of the water requirement of most of its surrounding regions (DENR, 2008).

Four selected lower order streams and tributaries around MMPL were selected for the study. The Linan Tributary, Glandang Tributary and Amlok Tributary are located in Tupi South Cotabato while the Kawit Tributary is situated in Polomolok South Cotabato. Three stations located upstream, midstream and downstream of each tributary were established. These three stations were located between $6^{\circ} 36^{\prime}$ and $36^{\circ} 37^{\prime}$ North latitude and between $125^{\circ} 04^{\prime}$ and $124^{\circ} 97^{\prime}$ 'East longitude for Linan Tributary at 273-1204 meters above sea level (masl); between $6^{\circ} 21^{\prime}$ and $6^{\circ} 19^{\prime} \mathrm{N}$ and between $125^{\circ} 2^{\prime}$ and $125^{\circ} 2.5^{\prime} \mathrm{E}$ for Glandang Tributary at 633-1079 masl; $6^{\circ} 25^{\prime} \mathrm{N}$ and $125^{\circ} 4^{\prime} \mathrm{E}$ for Amlok Tributary at 672-910 masl; and between $6^{\circ} 34^{\prime}$ and $6^{\circ} 32^{\prime} \mathrm{N}$ and $125^{\circ} 10^{\prime}$ and $125^{\circ} 12^{\prime}$ E for Kawit Tributary at 780960 masl. These tributaries are chosen on the basis of accessibility of the water resource for the nearby communities. These tributaries are heavily utilized by the locals for domestic water supply.

\section{Sampling}

Assessment for physicochemical parameters and water sampling was done between 10am to 


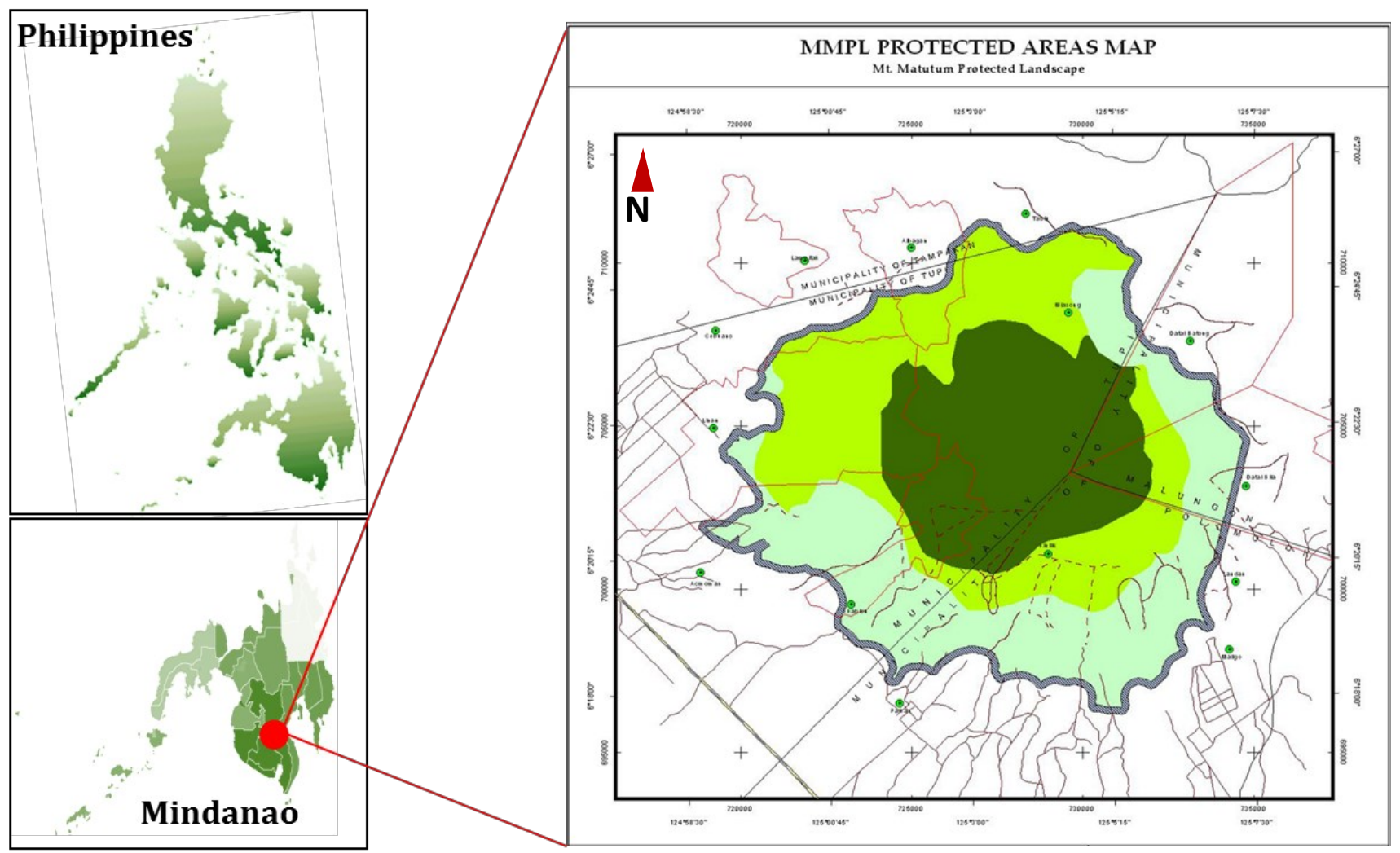

Figure 1. Study area. Map of the Philippines showing the location of Mt. Matutum Protected Landscape.

$4 \mathrm{pm}$ for all sites. Physico-chemical parameters for water quality were tested in situ using portable meters. Temperature and TDS were measured using TDS 3 digital meter. Lutron DO Meter and $\mathrm{pH} 80$ were used for measuring $\mathrm{DO}$ and $\mathrm{pH}$, respectively. In each tributary, the assessment was carried out with 27 readings spread across the upstream, midstream and downstream stations. For microbial parameters, samples were collected at about five (5) $\mathrm{cm}$ from the surface water layer at the center of the main flow. For each tributary, nine water samples were collected using disposable sterile sampling bags. The samples were stored in cold temperature for transport to the laboratory. Total coliform count and $E$. coli count were analyzed following the APHA-AWWA method. Sampling was done in two periods covering the wet season (December 2013) and the dry season (April 2014).

\section{Data Analysis}

Mean values for all parameters tested were computed and water quality assessment was done by comparing the results with the standard values. Temporal variation for all parameters was assessed using Student's t-test at 0.05 level of significance.

\section{Results and Discussion}

\section{Physico-chemical Assessment}

An attempt has been made to assess the water quality of the four selected tributaries in MMPL (Table 1). Physicochemical properties such as temperature, $\mathrm{pH}, \mathrm{DO}$ and TDS were measured in situ during wet and dry sampling periods. The physicochemical parameters were compared with the standard values set by DENR (DAO 34) while the microbial parameters were compared with the Environmental Protection Agency standards. Temperature readings in all sites show a narrow range with $21^{\circ} \mathrm{C}$ to $21.69^{\circ} \mathrm{C}$ readings for the wet season and $23.16{ }^{\circ} \mathrm{C}$ to $25.21{ }^{\circ} \mathrm{C}$ during the dry season. Data on temperature fall within the acceptable temperature difference of approximately $2^{\circ} \mathrm{C}$ in all sampling sites. Furthermore, a significant difference in temperature readings was observed between wet and dry seasons in all four sampling sites at $p<.05$ (Table 2 ).

In assessing water quality, $\mathrm{pH}$ is one crucial parameter to determine the suitability of water for various purposes (Yogendra and Puttaiah, 
JEEAR, Vol. 1, 2018

Table 1. Physicochemical profile of the four tributaries in Mt. Matutum taken during wet and dry seasons.

\begin{tabular}{cccccccccc}
\hline \multicolumn{1}{c}{$\begin{array}{c}\text { Parame- } \\
\text { ter }\end{array}$} & Wet & Dry & Wet & Dry & Wet & Dry & Wet & Dry & Std \\
\hline Temp & 21.00 & 24.82 & 21.24 & 23.16 & 21.69 & 24.00 & 21.22 & 24.95 & \multicolumn{2}{c}{ Amlok River } \\
pH & 8.11 & 6.10 & 7.60 & 6.75 & 8.27 & 7.04 & 8.68 & 7.44 & $\begin{array}{c}\text { Kandang River } \\
8.5\end{array}$ \\
DO $^{\mathrm{a}}$ & 2.54 & 5.11 & 2.42 & 5.21 & 2.32 & 4.32 & 2.89 & 5.54 & 5 \\
TDS $^{\mathrm{a}}$ & 149.33 & 146.30 & 68.15 & 55.96 & 221.93 & 176.52 & 148.33 & 108.48 & 500 \\
Coliform $^{\mathrm{b}}$ & 168.33 & 51.78 & 247.78 & 111.00 & 162.22 & 52.89 & 275.56 & 74.22 & $<20$ \\
E. coli $^{\mathrm{b}}$ & 50 & 6.22 & 0.56 & 7.22 & 77.78 & 13.44 & 5.56 & 1.78 & 1 \\
\hline
\end{tabular}

${ }^{a}$ in $m g / L$

${ }^{b}$ in $C F U / m L$

Table 2. Comparing water temperature between wet and dry seasons in the four sampling sites in Mt. Matutum.

\begin{tabular}{cccc}
\hline Sampling Site & \multicolumn{2}{c}{ Temperature $\left({ }^{\circ} \mathrm{C}\right)$} \\
$(\mathrm{n}=27)$ & $\begin{array}{c}\text { Dry Season } \\
(\mathrm{n}=27)\end{array}$ & t-value \\
\hline Kawit & $21.24 \pm 0.17$ & $23.16 \pm 0.18$ & $-12.09^{*}$ \\
Linan & $21.00 \pm 0.22$ & $24.82 \pm 0.48$ & $-12.82^{*}$ \\
Glandang & $21.69 \pm 0.16$ & $24.00 \pm 0.17$ & $-43.34^{*}$ \\
Amlok & $21.22 \pm 0.06$ & $24.95 \pm 0.07$ & $-38.50^{*}$ \\
\hline
\end{tabular}

Note: values are in mean $\pm S E ; *=p \leq 05$.

2008). The mean $\mathrm{pH}$ values of all samples taken from each site ranged from 7.18 to 8.07. Amlok stream waters showed the highest $\mathrm{pH}$ value (8.07) among the four sites. Nevertheless, these values are within the permissible levels recommended in DAO (1990) for pristine surface waters. Seasonal$1 \mathrm{y}$, the stream waters are more alkaline during the wet season with a maximum value of 8.68 recorded at Amlok tributary. This high $\mathrm{pH}$ may be attributed to the tilled lands adjacent to the sampling sites. During rainfall, the increased runoff would most likely result to increased levels of dissolved particles in water. These particles such as bicarbonates are responsible for increasing the $\mathrm{pH}$ of the water (Manjare et al., 2010). These differences in $\mathrm{pH}$ between wet and dry season are found to be statistically significant at $\mathrm{p}<.05$ (Table 3 ).

With respect to dissolved oxygen (DO), all values recorded for all sampling stations fall within the range $2.32-5.23 \mathrm{mg} / \mathrm{L}$. Majority of the values obtained are below the minimum recommended level for Class C Philippine classification for fresh 
JEEAR, Vol. 1, 2018

Table 3. Comparing $\mathrm{pH}$ between wet and dry seasons in the four sampling sites in Mt. Matutum.

\begin{tabular}{|c|c|c|c|}
\hline \multirow[t]{2}{*}{ Sampling Site } & \multicolumn{2}{|c|}{$\mathrm{pH}$} & \multirow[b]{2}{*}{ t-value } \\
\hline & $\begin{array}{l}\text { Wet Season } \\
\quad(\mathrm{n}=27)\end{array}$ & $\begin{array}{c}\text { Dry Season } \\
(\mathrm{n}=27)\end{array}$ & \\
\hline Kawit & $7.60 \pm 0.08$ & $6.75 \pm 0.04$ & $12.34 *$ \\
\hline Linan & $8.11 \pm 0.17$ & $6.10 \pm 0.19$ & $5.54 *$ \\
\hline Glandang & $8.27 \pm 0.15$ & $7.04 \pm 0.21$ & $19.05^{*}$ \\
\hline Amlok & $8.68 \pm 0.01$ & $7.44 \pm 0.02$ & $44.49^{*}$ \\
\hline
\end{tabular}

Note: values are in mean $\pm S E ; *=p \leq 05$.

waters $(5.0 \mathrm{mg} / \mathrm{L})$ set by DENR. In terms of temporal variation, DO levels are higher at all sites during the dry season than during the wet season. Similar patterns in the levels of DO were reported by Manjare et al. (2010) which were attributed to higher photosynthetic activities by aquatic producers resulting to the release and increase of $\mathrm{O} 2$ in the streams. The present study did not consider phytoplankton assessment to account for the increased DO levels during the dry season. Nevertheless, the differences in the DO levels for all four tributaries during the wet and dry seasons are statistically significant $(p<.05)$ suggesting that climatic conditions play a role in the dissolution of oxygen in water (Table 4).

The lowest DO values were recorded at Glandang tributary. Since DO concentrations regulate the abundance of biotic life with $>4 \mathrm{mg} / \mathrm{L}$ requirement for a healthy aquatic system (Eletta and
Adeloka, 2005), Glandang tributary can then be considered with low productivity, thereby not being able to support aquatic life. Observations of the locals show the reduction of aquatic life in their rivers. Local accounts noted he presence of freshwater species ('pait,' 'bakbak,' 'kasili') in Amlok, which are being caught mainly for subsistence. Contrary to this, Glandang tributary is devoid of fish due perhaps to the observed encroachment into the riverine system.

The total dissolved solids ranged from the lowest value of $56 \mathrm{mg} / \mathrm{L}$ in Kawit tributary to a significantly high value of $222 \mathrm{mg} / \mathrm{L}$ in Glandang tributary. These values conform to the standards set by DENR at $500 \mathrm{mg} / \mathrm{L}$ for Class $\mathrm{C}$ waters. High TDS values across the four sites are influenced by heavy rainfall during the wet season especially on sites near human settlements, and agricultural and industrial activities. Other authors (Banach et al.,

Table 4. Comparing DO between wet and dry seasons in the four sampling sites in Mt. Matutum.

\begin{tabular}{|c|c|c|c|}
\hline \multirow[t]{2}{*}{ Sampling Site } & \multicolumn{2}{|c|}{ Dissolved Oxygen (mg/L) } & \multirow[b]{2}{*}{ t-value } \\
\hline & $\begin{array}{l}\text { Wet Season } \\
\quad(\mathrm{n}=27)\end{array}$ & $\begin{array}{l}\text { Dry Season } \\
\quad(\mathrm{n}=27)\end{array}$ & \\
\hline Kawit & $2.42 \pm 0.02$ & $5.21 \pm 0.08$ & $-36.52 *$ \\
\hline Linan & $2.54 \pm 0.06$ & $5.11 \pm 0.08$ & $-19.72 *$ \\
\hline Glandang & $2.32 \pm 0.09$ & $4.32 \pm 0.17$ & $-13.91 *$ \\
\hline Amlok & $2.89 \pm 0.01$ & $5.54 \pm 0.18$ & $-15.19 *$ \\
\hline
\end{tabular}

Note: values are in mean $\pm S E ; *=p \leq .05$ 
2009, Ancog and Flavier, 2014) have similar observations in their studies of different water bodies. Significant variation $(p>.05)$ in TDS levels between wet and dry seasons was observed in the three tributaries but not in Linan with $\mathrm{p}>.05$ (Table 5).

\section{Microbial Analysis}

Mean values of the total coliform and $E$. coli counts in surface water for wet and dry seasons are presented in Table 6 and Table 7, respectively. Assessing the quality of water in terms of total coliform count disqualifies the four tributaries for domestic supply and recreation activities. Coliform and $E$. coli counts of all tributaries for both wet and dry seasons have exceeded the permissible levels set by EPA. Interviews with locals revealed high incidence of gastrointestinal disorders that could be attributed to drinking polluted water. Utilizing the water resource from the tributaries would then necessitate treatment prior to use to ensure human health ambient water quality.

The highest coliform count during wet season $(275.56 \mathrm{CFU} / \mathrm{mL})$ was recorded in Amlok tributary, followed by Kawit with a recorded 247.78 $\mathrm{CFU} / \mathrm{mL}$ count. Similarly, the two highest E. coli counts are also from the samples collected in Amlok and Kawit, with 75.22 CFU/mL and $111 \mathrm{CFU} /$ $\mathrm{mL}$, respectively. Notably, it is Amlok and Kawit that have the lowest $E$. coli counts for both wet and dry seasons. This condition is probable for a riverine system with dense forest cover and no human dwellings. Meanwhile, the other two tributaries, Linan, and Glandang, shared similar trends on their microbial load. It was noted that these two tributaries exhibited the highest E. coli counts thereby implying close human encounters and other anthropogenic activities.

Table 5. Comparing TDS between wet and dry seasons in the four sampling sites in Mt. Matutum.

\begin{tabular}{|c|c|c|c|}
\hline \multirow[t]{2}{*}{ Sampling Site } & \multicolumn{2}{|c|}{ Total Dissolved Solids (mg/L) } & \multirow[b]{2}{*}{ t-value } \\
\hline & $\begin{array}{l}\text { Wet Season } \\
\quad(\mathrm{n}=27)\end{array}$ & $\begin{array}{l}\text { Dry Season } \\
\quad(\mathrm{n}=27)\end{array}$ & \\
\hline Kawit & $68.15 \pm 2.24$ & $55.96 \pm 0.99$ & $6.26^{*}$ \\
\hline Linan & $149.33 \pm 15.26$ & $146.30 \pm 15.04$ & 0.26 \\
\hline Glandang & $221.93 \pm 16.01$ & $176.52 \pm 10.49$ & $7.61 *$ \\
\hline Amlok & $148.33 \pm 1.62$ & $108.48 \pm 3.13$ & $10.64 *$ \\
\hline
\end{tabular}

Note: values are in mean $\pm S E ; *=p \leq 05$.

Table 6. Comparing coliform count between wet and dry seasons in the four sampling sites in Mt. Matutum.

\begin{tabular}{cccc}
\hline Sampling Site & \multicolumn{2}{c}{ Coliform $(\mathrm{CFU} / \mathrm{mL})$} & \\
& $\begin{array}{c}\text { Wet Season } \\
(\mathrm{n}=9)\end{array}$ & $\begin{array}{c}\text { Dry Season } \\
(\mathrm{n}=9\end{array}$ & t-value \\
\hline Kawit & $247.78 \pm 69.49$ & $111.00 \pm 17.48$ & 1.99 \\
Linan & $168.33 \pm 42.38-$ & $51.78 \pm 14.59$ & $3.88^{*}$ \\
Glandang & $162.22 \pm 47.57$ & $52.89 \pm 13.16$ & $2.50^{*}$ \\
Amlok & $275.56 \pm 20.15$ & $74.22 \pm 9.69$ & $9.04^{*}$ \\
\hline
\end{tabular}

Note: values are in mean $\pm S E ; *=p \leq 05$. 
JEEAR, Vol. 1, 2018

Table 7. Comparing E. coli count between wet and dry seasons in the four sampling sites in Mt. Matutum.

\begin{tabular}{cccc}
\hline Sampling Site & \multicolumn{2}{c}{ E. coli $(\mathrm{CFU} / \mathrm{mL})$} & \\
& $\begin{array}{c}\text { Wet Season } \\
(\mathrm{n}=9)\end{array}$ & $\begin{array}{c}\text { Dry Season } \\
(\mathrm{n}=9\end{array}$ & t-value \\
\hline Kawit & $0.56 \pm 0.38$ & $7.22 \pm 3.04$ & 2.23 \\
Linan & $50 \pm 25.71$ & $6.22 \pm 1.99$ & 1.813 \\
Glandang & $77.78 \pm 68.02$ & $13.44 \pm 5.31$ & 0.962 \\
Amlok & $5.56 \pm 2.42$ & $1.78 \pm 0.85$ & 1.29 \\
\hline
\end{tabular}

Note: values are in mean $\pm S E ; *=p \leq 05$.

Total coliform does not necessarily indicate water contamination or the risk of water-borne illnesses (NHMRC, 2003) since these bacteria are metropolitan and can be naturally found in soils, surface water, and plants (O'neal and Hollrah, 2007) other than being found in the intestinal tracts of humans and animals. Accordingly, the results of total coliform counts in various streams/rivers within MMPL are not, in a direct manner, indicative of fecal contamination. Results of total coliform counts, specifically on Kawit and Amlok tributaries may, most likely, be accounted to weatherrelated events such as drought and heavy rainfall (EPA, 2006). Soil runoffs and erosions intensified by the occurrence of rainfall events that bring fecal matter into the water tributaries may explain why higher total coliform counts were observed during the wet season. Hill et al (2006) assessed the impact of rainfall on fecal coliform bacteria in Bayou Dorcheat in North Louisiana. They presented possible sources of elevated coliform counts in rivers and streams such as sewage discharges, storm water overflows, and runoff from pastures and range lands. A significant increase in the fecal coliform numbers is cited being associated with average rainfall amounts. Drastic increase in microbial densities were found to be significantly correlated with increased rainfall and streamflow (Shehane et al., 2005; Tornevi et al., 2014).

Similarly, higher coliform counts in all sampling sites in this study are observed during the wet season. Statistical analysis revealed significant variation in the coliform counts between wet and dry seasons in three sampling sites but not in Kawit tributary $(\mathrm{p}=0.81)$. The deviation of the pattern in Kawit may have been due to other contributing fac- tors such as the frequent human disturbance due to nursery activity near the sampling stations. Meanwhile, the E. coli counts recorded in all sampling sites did not differ significantly between wet and dry seasons. This means that climatic conditions do not significantly influence the number of $E$. coli in the surface waters.

Temperature is also considered as one of the factors affecting the proliferation rate of microorganisms (Agbabiaka and Sule, 2010). Sakyi and Asare (2012) reported that higher temperatures (approx. $37{ }^{\circ} \mathrm{C}$ and higher) significantly reduce bacterial proliferation while temperatures between 15 to $25^{\circ} \mathrm{C}$ may be ambient for bacterial survival, especially in a nutritionally-rich environment. Considering the temperature range recorded for the tributaries, it could be gleaned that surface waters provide ambient environmental conditions for microbial growth. Thus, presence and, to some extent, abundance of common microbial pollutants in rivers and streams were observed.

The presence of $E$. coli in surface waters is more revelatory of fecal contamination as it is found in higher numbers in fecal material and rarely occurs in the environment than other coliforms (NHMRC, 2003). The high levels of E. coli on Linan and Glandang rivers evidently suggest water contamination by fecal wastes. This relatively reveals the presence of other harmful disease-causing microorganisms more detrimental to human and animal health.

Both Linan and Glandang tributaries are especially noted in this study to be the most vulnerable to the consequences of anthropogenic activities as these tributaries are very near human settlements and agricultural farmlands. The elevated mi- 
crobial counts then may have resulted from indiscriminate dumping of waste and human feces which may be accounted to the lack of significant knowledge on sanitation and hygiene. With the marginal socio-economic status of most residents, the lack of sanitation facilities within the inhabiting community is assumed to be one major contributory factor for fecal contamination in surface waters. Thus, public health is being compromised, and a more stringent water quality monitoring is warranted.

Local water resources are utilized primarily for domestic use, agriculture, industry and commercial activities. The diverse uses of tributaries, rivers, and streams are greatly reduced if the water system is damaged by pollution and/or erosion due to large-scale deforestation and over grazing in watershed areas. As a result, the river's physicochemical quality becomes compromised destroying the aquatic community and disrupting the delicate food web in the ecosystem. Due to changing weather conditions that regulate the physicochemical and microbial profile of the surface waters, the already stressed water bodies may have been impacted more by anthropogenic activities which in return can pose more damage to humans.

\section{Conclusion}

Water quality assessment provided baseline information for the classification of the four selected tributaries in MMPL as Class C water following DENR Administrative Order 34. For most of the parameters tested, seasonal variation is seen in the physicochemical parameters in all rivers while none is revealed in terms of microbial load.

Rigid monitoring programs require numerous parameters to obtain accurate and timely information on the quality of surface water. As such, it is necessary to test the water quality of the tributaries and streams within MMPL encompassing various physicochemical parameters and extending the sampling periods on a monthly basis. This would then provide a more insightful data in order to classify the fresh water bodies and also to formulate sound public policies for the watershed's protection, conservation, and sustainability.

\section{Acknowledgment}

We are grateful for the funding support of the Commission on Higher Education, Philippines under their Grants-In-Aid Program for Research and Development. Our sincerest thanks to the LGUs and local community in Tupi and Polomolok for the assistance extended to us during the conduct of the study.

\section{References}

Agbabiaka, T.O., Sule, I.O. (2010). Bacteriological assessment of selected borehole water samples in Ilorin Metroplis. International Journal of Applied Biological Research, 2(2), 31-37.

Ajayi, A.A., Peter-Albert, C.F., Ajojesu, T.P., Bishop, S.A., Olasehinde, G.I. and Siyanbola, T.O. (2016). Biochemical oxygen demand and carbonaceous oxygen demand of the Covenant University sewage oxidation pond. Covenant Journal of Physical and Life Sciences 4(1): 11-19.

Ancog, R.C., Flavier, M.E. (2014). Comparative water quality of major tributaries of large marine ecosystem: The case of Verde Island Passage Marine Corridor Philippines. Asia Life Sciences, 23(1), 93-105.

Anhwange, B.A., Agbaji, E.B., Gimba, E.C. (2012). Impact assessment of human activities and seasonal variation on River Benue within Makurdi Metropolis. International Journal of Science and Technology, 2(5), 248-254.

Amanaditou, E., Adamidou, K., Trikoilidou, E., Katsiouli, F., Patrikaki, O., Tsikritzis, L. (2003). Physicochemical and microbiological characteristics of the potable water supply sources in the area of Kozani, Western Macedonia. Desalination, 213, $1-8$.

Banach, A.M., Banach, K., Peters, R.C.J.H., Jansen, R.H.M., Visser, E.J.W., Stepniewska, Z., Roelofs, J.G.M., Lamers, L.P.M. (2009). Effects of long-term flooding on biogeochemistry and vegetation development in floodplains; a mesocosm experiment to study interacting effects of land use and water quality. Biogeosciences, 6, 1325-1339.

Calin, D.I., Rosu, C. (2011). Drinking water quality assessment of rural wells from Aiud Area. AES Bioflux 3(2), 108-122.

DENR (2008). Southern Mindanao Integrated Coastal Zone Management Project. PH-P194 http:// faspselib.denr.gov.ph.

(DOW). Department of Water. (2005). Surface wa- 
ter sampling methods and analysis - technical appendices. Standard operating procedures for water sampling - methods and analysis. Australia. Retrieved from www.water.wa.gov.au.

Eletta, O.A.A., Adekola, F.A. (2005). Studies on the physical and chemical properties of Asa River Water, Kwara State, Nigeria. Science Focus, 10(1), 72-76.

(EPA). Environmental Protection Agency. (2006). Causes of total coliform-positive occurrences in distribution systems. Retrieved from www.epa.gov on May 21, 2013.

Hill, D.D., Owens, W.E. and Tchounwon, P.B. (2006). The impact of rainfall on fecal coliform bacteria in Bayou Dorcheat, North Louisiana. International Journal of Environmental Research and Public Health, 3(1): 114-117.

Joshi, D.M., Kumar, A., Namita, A. (2009). Studies on physicochemical parameters to assess the water quality of River Ganga for drinking purpose in Haridwar District. Rasayan J. Chem., 2(1), 195203.

Kushwa, R.K., Bajpai, A., Malik, S., Singh, A. (2011). Seasonal variation of physicochemical parameters of waste water from a sewage treatment plant, Bhopal India. International Journal of Chemical Science, 9(3), 1545-1552.

Line, D.E. (2003). Changes in a stream's physical and biological conditions following livestock exclusion. American Society of Agricultural Engineers, 46(2), 287-293.

Malini, S., Nagaiah, N., Paramesh, L., Venkataramaiah, P., Balasupramaniam, A. (2003). Ground water quality around Mysore City, Kamataka, India. Intem. Journal of Environmental Studies. 60:87 -98 .

Manjare, S.A., Vhanalakar, S.A., Muley, D.V. (2010). Analysis of water quality using physicochemical parameters Tamdalge Tank in Kolhapur District, Maharashtra. International Journal of Advanced Biotechnology and Research, 1(2), 115119.

(NHMRC). National Health and Medical Research Council. (2003). Recommendations to change the use of coliforms as microbial indicators of drinking water quality. Review of Coliforms as microbial indicators of drinking water quality. Biotext Pty Ltd, Canberra Australia. Retrieved from www.nhmrc.gov.au on May 6, 2014.

Nduka, J.K., Orisakwe, O.E., Ezenweke, L.O. (2008). Some physicochemical parameters of potable water supply in Warri, Niger Delta area of Nigeria. Scientific Research and Essay, 3(11), 547551.

Ngidlo, R.T. (2013). Impacts of pesticides and fertilizers on soil, tail water and groundwater in three vegetable producing areas in the Cordillera Region, Northern Philippines. American Journal of Experimental Agriculture, 3(4), 780-793.

O'neal, S.W., Hollrah, D.N. (2007). Monitoring of total coliform and Escherichia coli levels in second order stream in West-Central Oklahoma. Proceedings of Oklahoma Academy of Science 87, 69-75.

Perlman, H. (2014). Water properties: dissolved oxygen. U.S. Department of Interior. U.S. Geological Survey. Retrieved from http://water.usgs.gov/ edu/dissolvedoxygen/html on Dec 29, 2014.

Rout, C., Sharma, A. (2011). Assessment of drinking water quality: A case study of Ambala cantonment area, Haryana, India. International Journal of Environmental Sciences, 2(2), 933-945.

Sakyi, P.A., Asare, R. (2012). Impact of temperature on bacterial growth and survival in drinkingwater pipes. Res. J. Environ. Earth Sci., 4(8), 807817.

Shehani, S.D., Harwood, V.J., Whitlock, J.E. and Rose, J.B. (2005). The influence of rainfall on the incidence of microbial faecal indicators and the dominant sources of faecal pollution in a Florida river. Journal of Applied Microbiology, 98: 11271136.

Tampus, A.D., Tobias, E.G., Amaprado, R.F., Bajo, L., Sinco, A.L. (2012). Water quality assessment using macroinvertebrates and physicochemical parameters in the riverine system of Iligan City, Philippines. Advances in Environmental Sciences-Internation Journal of the Bioflux Society, 4(2), 59-68.

Tornevi, A., Bergstedt, O. and Forsberg, B. (2014). Precipitation effects on microbial pollution in a 
River: Lag structures and seasonal effect modification. PLoS One 9(5): e98546. https:// doi.org/10.1371/journal.pone.0098546

Tripathi, K., Sharma, A.K. (2011). Seasonal variation in bacterial contamination of water sources with antibiotic resistant faecal coliforms in relation to pollution. Journal of Applied and Natural Science 3(2), 298-302.

Venkateswarlu, V. (1993). Ecological studies on the rivers of Andhra Pradesh with special reference to water quality and pollution. Proceedings of the Indian Academy of Science, 96, 495-508.

World Health Organization (WHO). (2004). Guidelines for drinking water quality. 3rd edition. Vol. I. Recommendations, World Health Organization. Geneva.

Yogendra, K., Puttaiah, E.T. (2008). Determination of water quality index and suitability of urban waterbody in Shimoga Town, Karnataka. Proceedings of Taal 2007: The 12th World Lake Conference, 342-346. 